\title{
Abstracts of Some Recent Papers
}

\section{SOCIAL ANTHROPOLOGY}

F. VAN DE GINSTE, 'Le Mariage chez les Basuku', Bulletin des Juridictions indigenes et du Droit coutumier congolais, Élisabethville; Isth year, Nos. I, 2, Jan.-Feb., March-April, 1947. The Basuku number about 78,000 and occupy the central part of the Kwango district of Belgian Congo. Endogamy is practised because theoretically within the clan there are no palavers or, if they occur, are easily settled. Bride-wealth is less than in exogamous marriages and is not given back if the union is broken. Exogamous marriages are patrilocal, and the children belong to the wife's clan. The marriage ceremony consists of two acts separated by several months. The first is the delivery of the bride-wealth to the girl's father in the presence of a witness : before the recent war this was valued at I 50-250 francs, but now at 250-500 or even I,000. The present high amount prevents many men from marrying and is an indirect cause of polygamy. After the bride-wealth has been transferred the couple may cohabit without penetration for about six months and the man may then repudiate the girl if not satisfied with her. If all has gone well, the couple repair to the girl's uncle's village with a goat which the bridegroom has purchased, and there a ceremony which is essentially religious takes place at the crossing of two roads : the goat is killed and there are other acts all designed to separate the girl from the influence of her father's and uncle's fetishes, and bind her to her husband's. This completes the marriage. When man and wife are so devoted to each other that they wish the relationship to continue in the next world, they either mix some of their blood in a small pot and bury it or they suck each other's blood, thus pledging themselves to a strict monogamy. In former times chiefs had from ten to thirty wives but the number of big polygamists is now greatly reduced. The favourite wife is named fuama, 'friend, confidant '; she may or may not be the mombanda, the first or chief wife, who is taken from the chief's own clan so that she may be associated with him in the ancestral cult: she alone is permitted to touch his fetishes. When a second wife is taken a special ceremony is held, the food for which is prepared by the first wife and is intended to remove any jealousy (kimpala) between them. If the husband slept with the new wife without this ceremony, and if subsequently the mombanda and her children fell ill, he would be blamed. If one of the wives gives birth he may have no sexual intercourse with the others before the ceremony which celebrates the emergence of the child from the house. These reasons are assigned for polygamy: (I) the excess of females; (2) le sevrage; (3) menstruation; (4) the levirate; (5) economic and social causes; $(6)$ sexual interdictions. Precise statistics over a number of years show that 96 or 97 girls are born for every 100 boys; but for every 100 adult males there are 130 females. The author applies the word sevrage to the separation of a man from his wife from the sixth month of pregnancy till the end of lactation, which lasts two or three years. If a woman conceives again within this period, and if no misfortune befalls her or the other children, the affair is accepted; but if it befalls, the husband is held responsible. Abortion is frequent and meets with no reprobation in such cases. During the menstrual period the husband not only keeps aloof but may not eat food prepared by his wife; and she is subject to various restrictions, some of which apply also to him. The levirate is connected with polygamy seeing that a man may have wives thrust upon him at the death of his brother. The Basuku have the widespread root for 'tabu' ( $k i$-sila; cf. Zulu -zila); and a special tabu, kedila, suspends normal sex relations in certain circumstances: it is imposed on the wife by her maternal uncle for from one month to two years. If, for example, a man is caught stealing cattle, the owner may place him under the influence of 
his fetishes and the man's wife's uncle may impose the kedila until the affair is settled. One of a man's children or his wife may be stricken with disease and the wife is consequently. accused of having had extra-conjugal relations. She confesses and her uncle imposes kedila until her lovers have all paid up. The palavers may go on for a long time and meanwhile the conjugal life is empoisoned. When a child is born after resumption of relations it is given a special name, ngumbwa; its hair may not be cut without the uncle's permission; and during this time, perhaps two years, kedila is still in force, relations are again suspended. If the child dies within this period, the affair is extremely grave. The diviner may say the uncle is responsible, but if he blames the husband the husband may be fined up to 200 francs and a new kedila is imposed until he pays; if he cannot pay, the marriage is dissolved. The author denounces this custom as anti-social and contrary to public morality. It must affect the birth-rate and its abuse is traceable to the venality of the uncle who takes advantage of it to exploit his niece's husband. The happiest woman in the tribe is she whose uncle dies.

F. VAN DE GINSTE, 'Le Lupambula chez les Basuku', Bulletin des Juridictions indigènes et du Droit coutumier congolais, Élisabethville; $\mathrm{x}$ sth year, No. I, Jan.-Feb. 1947. Lupambula is a species of religious syncretism and has the purpose of waging an organized and efficient warfare against sorcery by a general destruction of fetishes and the fusion of manism with elements of Christian origin, notably confession of sins followed by absolution and regeneration to a new life by means of a benediction through holy water. Originating on the banks of the Kasai, in 1945 it penetrated to the Basuku and everywhere gained success. It declares that the misfortunes and death that befall us come solely from the sorcerers (ndokibandoki) and the secret bad fetishes which are in their power; these must all be annihilated. The author describes the six weapons which adherents are given for the conflict; they are various charms which impart confidence and certitude that no sorcerer can harm the adherent. There are seven grades in the hierarchy, each of which has its function. The head dignitary, Tata Mulamba, has charge of organization and discipline; the second is Sha Mapinga who must be a converted sorcerer; the third is Mwana Shia who guards the ancestor cult and sees to the destruction of fetishes; others know the secrets of preparing holy water and of various powders. These officers are appointed in each village which accepts the coming of the sect. It has its own fetishes and its own rules and tabus. Adepts are under the obligation to aid, sustain, and give hospitality to other members even though they be of a different clan and tribe. They may not eat food that is not prepared by their wives or members of the sect. Sexual restrictions are removed; adepts can practise adultery without great danger; the outraged husband simply gives his wife some of the effective powder of the sect. There are certain alimentary tabus. Lupambula is the enemy of fetishism but supports manism: offerings are given to appease ancestors who were sorcerers and since one never knows who were sorcerers all ancestors are propitiated. By the elimination of actual fetishes one assures the repose of future generations. As in all modern African religious movements, we find in Lupambula elements borrowed from Christianity. Public confession serves to maintain tabus and rules; it is done to the Sha Mapinga in the presence of the fetishes which are offended by the person's fault. If his repentance is sincere he receives a benediction in the form of holy water with an injunction to sin no more. On initiation an adherent drinks the water as a sign of new life in the course of which he will never act the sorcerer. Up to now the sect has never shown hostility towards the State. All efforts to suppress it have failed because the people live in dread of sorcerers and any movement aimed against them is sure of favour and support. Some really believe in it; others, freethinkers who believe neither in fetishism nor ancestral spirits, exploit it to their own advantage.

I Should this not be ndoki, sing.; bandoki, plut.?-Ed. 
G. E. J.-B. BrausCh, 'Le Group social comme synthèse créatrice', Bulletin du Centre d'Etude des problemes sociaux indigènes, C.E.P.S.I., Élisabethville; year 1946-7, No. 3. The purpose of this atticle is to study the measure in which the Nkutshu people of Belgian Congo shared in power, and to analyse the institutions through which they imposed their will in the domain of economics, justice, education, and politics, in order to discover the rules to which modern administration must conform to obtain a spontaneous and complete co-operation on the part of all classes of the people. The Nkutshu régime is based upon relations created between social groups that are more or less egalitarian. There is no predominant group as in European societies, only a complicated system of associations which are based upon the economic and social needs of the community. The Leopard fraternity is a political association charged with the maintenance of order; and with it are intimately linked the corps of warriors, which catries out its decisions, and the Serpent society which is in part an initiation school in which the young are taught the principles of the social and political organization and in part a consultative council of the people $v i s-d-v i s$ the Leopard society. In the second rank are the corporations of artisans concerned with the economic interests of their members and with the prestige of the various crafts; the medical corps whose duty is to care for the physical and psychological health of the community; the association of hunting magicians; and the association of musicians. The professional associations are constantly engaged, one against another, in a struggle for supremacy and the arbiter is public opinion. An analysis of these groups reveals the structure of Nkutshu society; they are the essential organs without which the society could neither live nor act. The community and associations are supreme over the individual members; but the fact that an individual must submit to the group does not mean that he has lost all liberty of action. He has much liberty but it is exercised within an association. The isolated individual is impotent except within a group and supported by a group. Numerous examples of this fact are supplied by Nkutshu history. Ethnologists, the author complains, have, with some exceptions, gravely neglected the study of groups and associations, excepting communities and kin groups, because they think that these groups do not fulfil distinct functions and are all based upon kinship. To be a member of a kin group does not imply that one shares necessarily with one's kin in the same rights and duties; these differ as one belongs to this or that association. Nkutshu society has in simple form a system of differentiated functional groups which, like those of modern western civilization, engender group characteristics which form the basis for a study of group ethnology. Reality completely denies the theory of some ethnologists that native society is governed by rigidly fixed laws. Customs differ according to groups; they are group phenomena and propetly belong to a group. Instead of studying social structure in terms of customs, as is usually done, we should try to understand customs in terms of the groups within which they act, for customs have no existence as independent entities but only as functions of the groups. M. Brausch illustrates his point by asking why marriage is more solidly based in one section of the population than in another, in spite of the fact that in the former the percentage of illegitimate births is very high and is almost nil in the latter. The explanation is found in the existence of pre-nuptial associations in the former in which the young people have abundant opportunity of choosing their partners, while in the latter the girls usually accept the suitors chosen by their parents.

The ethnology of groups is diametrically opposed to the descriptive monographic method in so much as the latter gives a picture of customs as static and ignores the vital force which is proper to society. By a study of groups we come nearer to reality: we observe a changing and dynamic unity. M. Brausch finds support for this view in the history of the Leopard society. All the cultural changes revealed by the history of the Nkutshu are accomplished under the influence of groups, not by individual action. He asks: are the old rules of social 
change equally applicable to the events of to-day? The Nkutshu endeavour by means of their associations to overcome the difficulties which hinder them from progressing. The average individual has little chance now of sharing, as in the past, in political power. Europeans take all the important decisions in a way completely strange to the people. No account is taken of the traditional social structure. The Serpent society and hunting clubs are forbidden; many missionaries and administrators adopt a hostile attitude towards the medical corporation and the association of hunting magicians and pitilessly persecute members for innocent practices. The individual has lost all his rights and a new elite of recognized chiefs, judges, catechists, and clerks has come into power. The Nkutshu are bewildered by numerous economic and political problems which they cannot solve. Their traditional associations had all an educational character. In the modern set-up there is no association which teaches the natives notions of the modern institutions, new customs and manners, new principles of law, new labour techniques, \&c. There is no longer mass education for the society; on the contrary, by interdicting the most active associations European authority has destroyed the traditional education. Individuals seek a way out from this chaotic situation. A reaction has set in, marked by reappearance of the ancient institutions, and all efforts of the State fail to master such movements. New principles, new aspirations, partly influenced by ancestral cults and partly by western civilization but adapted to modern conditions, new religious sects, are being born. It is in these young movements, these new associations, that we must seek the principles which will offer us a solution for the future if we wish to build upon a solid foundation. Our modern administrative system must be based upon the organization, or upon the spirit, of the indigenous society-a system of functional groups. Tradition has its importance but is not an end in itself. To be significative it must be living, i.e. the expression of the interests and desires of the moment. We must therefore encourage only the viable groups, such as the kin-groups, the Leopard society with its judicial functions, the artisans' corporations, and the associations of musicians. The new organization must be constructive as well as conservative and the ancient associations must eventually adapt themselves to new forms, for otherwise they will disappear. The medical corporations should be taught the empirical principles of modern medicine; the Serpent society could be reformed into a school wherein would be taught not only the archaic social organization but equally the new set-up engendered by cultural contacts with European civilization. And so on. Finally, new associations should meet the new needs: e.g. co-operatives for agriculture by which modern methods are taught. It is only by constructing a new social structure in which groups and associations to serve new interests are provided that we shall succeed in re-establishing equilibrium in African society. The interaction of traditional African influences and Western influences has engendered a neo-African culture with which willy-nilly we must take account. In that new society, as in the ancient, the group must continue to play its part of creative synthesis.

Madame René Dugast, 'Une Corbeille divinatoire', Bulletin de la societé d'etudes camerounaises, Douala; 1946, Nos. 15-16, Sept.-Dec. Describes divination as practised among the Banen. To be a diviner (mondo w'engamb) one needs a special gift; it is not enough to learn certain formulas; one must be psychically in contact with the material. Some people inherit bibune, mysterious visceral parts localized near the stomach, which confer the special gifts, both of powers of olemb (witchcraft) and of interpreting dreams and of divining. It is the bibune that give knowledge of invisible things and establish intimate and direct contact between the internal being of the diviner and his divinatory objects. Divination can also be acquired. Fowls have bibune (residing in the blind gut, or the gut itself) and the aspirant abstracts the part from a fowl, mixes it with crushed herbs and a little salt, and swallows it raw in a draught of palm-wine. So he appropriates the virtue of the bibune; and by pouring 
the blood of the same fowl over the divinatory objects he is brought into contact with them. Of the several methods of divination, Madame Dugast studies one which consists in the manipulation of shells (bebando) of the fruit of the tree Oldfieldia africana. These are not regarded as simple material things : they share in the life of man; they have been through a process which has made them beings aware of a world that is unknown to ordinary men. Each of the 120 shells in the basket is marked differently and easily recognized: each has its own significance. They are here figured and described. A consultation is narrated. A man named Muteka comes to Batukini the diviner and puts the question: 'Shall I go on this journey?' After some preparatory flourishes Batukini throws out the bebando in a rotatory movement and reads their message which is not propitious; he then asks the bebando to show the talismans which will avert from Muteka all perils of the journey; and Muteka goes off after paying the fee of I franc so.

\section{PHYSICAL ANTHROPOLOGY}

Dr. Georges Olivier, 'Documents anthropométriques pour servir à l'étude des principales populations du sud-Cameroun', Bulletin de la societé d'etudes camerounaises, Douala; I946, Nos. I5-16, Sept.-Dec. Presents the combined findings of Dr. Olivier and five colleagues on the measurement of (in most instances) over 20 males and 20 females in 33 tribal groups, with some reference to languages and blood groupings. This paper should be read together with another in the same journal, 'Contribution a l'établissement d'un inventaire ethnique du Cameroun', by $\mathrm{H}$. de Pedralo. Here the approach is ethnographical and linguistic; and the classification of the Sudanian and Sudano-Bantu groups closely follows Delafosse. The Bantu group is subdivided thus : (a) Beninian sub-group, showing influence of Benin culture on a racial Bantu foundation; $(b)$ the Fang sub-group; $(c)$ old forest sub-group of the Ngoko and Upper Nyong rivers.

\section{LINGUISTIC}

Vinigi L. Grottanelli, ‘ Acconciatura e vestiario dei Koma al confine Etiopico-Sudanese’, Annali Laterenansi, vol. ix, 1945 and 'Materiali di lingua Coma', Rassegna di studi Etiopici, vol. $\mathrm{v}, \mathrm{I} 946$.

There lie between the Hamitic and Semitic block (Galla and Ambara) of Abyssinia and the Nilotic and Nilo-Hamitic block of the Sudan many little broken-up peoples (Splittervolk) who fit culturally and linguistically into neither block. Even to the African ethnologist they are little more than names: Berta, Mao, Masongo, Koma, \&c. In the July number of Africa for 1947 Professor Cerulli has added to our information about one group of these little peoples, the Berta, among whom I made my first anthropological survey in 1926-7. Professor Grottanelli has in these two papers added to our knowledge of another group, the Koma. The first Koma vocabulary was collected by the Dutch explorer J. M. Schuver and published by C. M. Kan in 1883 . In 1938 (Sudan Notes and Records, vol. xxi) Mr. F. D. Corfield of the Sudan Political Service devoted an article to the Koma of the Sudan. Mr. Corfield divided them into two groups, the Ciita and the Madin. Schuver's vocabulary corresponds with neither of those recorded by Mr. Corfield, so it is evident that there is a north-eastern group of so-called Koma who share little in common with the Koma of the Sudan except the name by which they have become known. The presence of these north-eastern Koma in Abyssinia is confirmed by Professor Grottanelli. He found that there were two groups of Koma in the region of the Yabus and Hudush rivers where he made his studies, the one (the Hudush group) speaking a language corresponding to that recorded by Mr. Corfield for the Madin and the other (the Yabus group) a language corresponding to that of which Schuver collected specimens. Professor Grottanelli therefore concludes that the Koma 
are divided into two linguistic groups : (a) a group to the north-east in Abyssinian territory, and $(b)$ a group to the south-west in Sudanese territory, divided into two sub-groups, the Ciita and the Madin, the Madin being found also on the Sudan-Ethiopian border farther to the north than any of the other Koma. The two groups appear to have little linguistically in common. Some other Koma fragments to the south of the Sudanese Madin appear to belong to group $(b)$.

E. E. Evans-Pritchard

\section{ARCHAEOLOGY}

Jean-Paul Lebeuf, 'Fouilles archéologiques dans la région du Tchad', Zaîre, Brussels, May 1947. The northern part of the Chad plain, inhabited formerly by the Sao, is rich in archaeological remains-nearly 9,000 objects have come to light. This article tells of findings at an ancient Sao village, Logone-Birni, at Fort Lamy, and at Midigue. At the last-named place was found the head of a gazelle in bronze, a small thing of extreme delicacy. The collections made allow some idea to be formed of the ancient culture and of the Sao. They worked in iron, copper, and bronze; their technique in pottery was astonishingly developed. The discovery of objects in bronze where the presence of that metal had been resolutely denied opens new horizons on the relations that may have at one time existed between the plain of Chad and the valley of the Nile. An attempt is made at dating this culture. The statuettes of horses in the lowest levels of excavation show that the first occupation was later than the twelfth century when the horse is known to have arrived in this region; the discovery of pipes in the latest levels points to a date later than the sixteenth century when tobacco was introduced into Africa. The conclusion is that the bulk of the collected material is distributed between the twelfth and eighteenth centuries and the greater part dates from the sixteenth. It is difficult to decide as to origins; but it seems certain that the material represents a unity of civilization either of one people or of two groups (Sao and Kotoko) one of which issued from the other.

\section{EDUCATION}

A special Correspondent, 'Education in the Sudan', The Times, 9 July 1947. Gordon College at Khartoum, an institution much esteemed by the Sudanese, is of university college standing and is directed by its own council. Its studies for the B.A. and B.Sc. degrees are co-ordinated with those of London University. When the British Government made a grant of $£ 2$ million to the Sudanese in recognition of war services, the Sudan Government allocated half the sum to the college, to which it already gives a subsidy of $£ 70,000$ a year. The 240 students pay nominal fees of about $£$ IO per annum. These facts point to the extent to which the administration is working to educate young Sudanese for responsible posts. The college plans to take in 690 students by 1955 . Lack of accommodation and the limitations of secondary school education necessarily slow down expansion. The 700 boarders in the two present government secondary schools are to be raised to over r,000 by 1949 ; there are also a few non-government schools. Tradition has hampered the progress of advanced education for Sudanese girls; to-day there are no more than 8,000 at government primary schools. A large part of the grant of $f_{\mathrm{I}} \mathrm{million}$ is to be spent on a new secondary establishment for boys; this will add considerably to the yearly quota of 180 students expected to reach Gordon College from secondary schools by i950. The Kitchener School of Medicine for the training of Sudanese doctors is expected to become an integral part of the college. The time may shortly come when a University of the Sudan will be authorized to award its own degrees. A first step in that direction was made by the Sudan Government's decision to invest full control of the affairs of the Gordon College in an independent council, one-third of its members being Sudanese. 